Rebkalo M. M.,

Ph.D. in State Governance, Associate Professor of the Department of Theory and History of State and Law, Constitutional Law, Academy of the State Penitentiary Service, Chernihiv, Ukraine

\title{
FORMS OF PROFESSIONAL SKILLS IMPROVEMENT OF THE PERSONNEL OF THE STATE CRIMINAL AND EXECUTIVE SERVICE OF UKRAINE: ADVANTAGES AND DISADVANTAGES
}

The analysis of the state of scientific development of Professional Skills Imrovemen System of persons of ordinary and commanding staff was carried out.It was defined, that the process of professional skills improvement is maintained through external and internal forms. The subjects who make professional skills improvement of the staff of Criminal and Executive Service were defined. Among them the institutions of the State Criminal and Executive Service and educational establishments, which are obeyed to the central and local bodies of Executive Authority should be named. Advantages and disadvantages both of external and internal forms of professional skills improvement are analyzed.Conclusions concerning the effectiveness of combination in current System of personnel's Professional Skills Imrovement external and internal forms mastering of staff's professional skills are formulated.

The author states that combination of external and internal forms of professional skills improvement creates the possibility to improve professional knowledge and habits based on innovative ideas and advanced experience in different spheres of social activity; combination of external and internal forms of professional skills improvement allows to attract representatives of all professions who are in the penitentiary service to the educational process; combination of external and internal forms of professional skills improvement significantly extends the quality of the educational process using the best educational and methodological achievements of the departmental and also other educational institutions which provide upgrading of personnel's personal skills.

Key words: The State Criminal and Executive Service of Ukraine, penitentiary personnel, the system of personnel's professional skills improvement, external forms of professional skills improvement, internal shapes of professional skills improvement, advantages and disadvantages of personnel's professional skills improvement.

Target setting. Changes that take place in the field of execution of punishments make topical the task of creating conditions for constant development of each employee's abilities, and therefore put forward new requirements to current system of professional training, an integral part of which is professional skills improvement. This approach significantly contributes to the development of staff's profes- 
sionalism, integration of which in the process of service, as practice shows, significantly improves the efficiency of performance of official duties. That's why it is not by chance that during the last decade the problems of organizing and improving the process of professional development are constantly in scientists and practitioners' sight. Scientists who carry out scientific development of a system of militarized and civilian civil servants' professional skills improvement investigate all the aspects of this activity.

Actual scientific researches and issues analysis. According to T. Kahanovska, the system of training, retraining and professional skills improvement of civil servants should be regarded as a single, integral subsystem in the system of personnel provision of public administration, from the state and level of which the efficiency and rationality of public administration depends on [1].

Butko M., one of the elements of the improvement of human resources in executive and local self-government bodies, seeks to teach this category of persons to use their personal professional reserves effectively in order to meet everyone's needs in retraining and raising their qualifications, as well as to create a system of graduation, maximally take into account new tasks in the field of civil service [2].

Chaika L. points out the necessity of targeted approach in dealing with different categories of civil servants, involvement in teaching at the courses of professional skills improvement managerial personnel of regional bodies, ensuring informational orientation of the content of training, the introduction of various forms in this process, etc. [3].

Kisil Z. believes that the personnel's of internal affairs bodies professional training is normatively regulated, organized, continuous and purposeful process of mastering special knowledge, abilities and skills necessary for the successful implementation of the official duties assigned to the persons of ordinary and commanding staff, and also the realization of the rights granted to them [4].

Duka O., analyzing the problems of the personnel's of the Criminal and Executive Service legal education, argues that the main task of this process is the transition to a personally oriented studying aimed at mastering the modern system of knowledge, skills and abilities, ways of creative activity, value orientations necessary for the accomplishment 
the state of tasks of correction and re-socialization of convicts, preparing them for adaptation in social life after the release [5].

Consequently, mentioned above points of view concerning the content and peculiarities of the system of professional skills improvement and its importance for improving the professionalism of civil servants working in various government agencies deserve attention. But the service in penitentiary authorities is a special type of civil service, which has specific tasks, and that's why the details of some aspects of staff's professionalism improving in terms of bringing the latter to international penitentiary standards becomes relevant.

The purpose of the article is to study the advantages and disadvantages of the system of professional skills improvement which is current in the field of execution of punishments as a necessary component of penitentiary staff's professional level improving.

The statement of basic materials. Professional training is oriented at the development and creative self-realization of the every worker of the criminal and executive service. Professional training is to provide getting and improvement of professional knowledge, special skills, and habits, necessary for the successful implementation of the official duties. The content of professional skills improvement is defined in The Act of Ukraine «On the State Criminal and Executive Service» and in the provision on the professional training of the persons of ordinary and commanding staff of the State Criminal and Executive Service of Ukraine.

Professional skills improvement is a process of getting additional knowledge by persons of ordinary and commanding staff and implementation of tasks and duties within their specialty. Persons of ordinary and commanding staff who have vocational and technical education or higher education take professional skills improvement courses in the Institutions of higher education of criminal and executive service, institutions of higher education of other central executive bodies not less than once five years.

There are two forms of professional skills improvement: in the institutions of higher education of the central executive bodies, local executive bodies (external forms); in the institutions of the State Criminal and Executive Service of Ukraine (internal forms). 
The External form of professional skills improvement means versatile meeting the requirements of the applied nature of the personnel at their work. There are different models for updating the system of education in regional institutions of professional skills improvement (centers). The first one is an integral system of professional skills improvement which provides the unity of the education process and adequate education technologies. The second one is a variational model that means elaboration of a certain side of the profession, which is to be improved. The model based on diagnostics is widely used. The essence of the last one is monitoring knowledge obtained by listeners.

There are some advantages of the external form: training is based on the majority of professions available at penal institutions, training is based on the programs tested in use and the educational plans; possibility of getting knowledge by implementing the innovation technologies. And there are some disadvantages: insufficient representation of the professional activity peculiarities of the personnel of penal institutions and probation during the process of training; regional centers don't establish the general purpose system of the professional skills improvement institutions which could be developed in the interaction with other social systems. Listeners are provided with the scripts of the educational events and with algorithms of the professional activity analysis.

The internal form provides for a participation of the State Criminal and Executive Service institutions in the educational process. The development of personnel's professional skills, formation of the ability to define their own professional abilities and changing the attitude to the service activity are the purpose of the internal form.

There is a structure of bodies which provide professional training of persons of ordinary and commanding staff includes bodies which control personnel's professional training and bodies which provide the professional training of persons of ordinary and commanding staff.

The personnel department of the State Criminal and Executive Service and regional authorities of the State Criminal and Executive Service are in the first group. They are to define the prospects and ways of personnel's of professional skills improvement, to control 
observance of the legal acts on professional training, to monitor the professional training process. Academy of the State penitentiary service of Ukraine, Bilatserkva center of the personnel upgrading; college of personnel qualification upgrading in Khmelnitsky are the second group of subjects witch organize professional skills improvement.

There are some advantages of the internal form of the professional professional skills improvement training. They are upgrading the professional knowledge by specialists who have great working experience in penal institutions; formation of skills and habits of the criminal and executive process analysis; improving the level of professional skills based on the existing innovative achievements in the system; improving the personnel's professional and cultural level, motivafion of the service activity; the improvement of methods and interaction style with NGOs and volunteer organizations. And there are some disadvantages of this form: limited specialties, which are to be improved, mostly they are lawyers; more often the personnel take the professional training when they do not perform the their service duties, only persons of ordinary and commanding staff are to take professional skills improvement courses, and civilian personnel are not sufficiently involved in this process.

Conclusions. In conclusion the author states that combination of external and internal forms of professional skills improvement creates the possibility to improve professional knowledge and habits based on innovative ideas and advanced experience in different spheres of social activity; combination of external and internal forms of professional skills improvement allows to attract representatives of all professions who are in the penitentiary service to the educational process; combination of external and internal forms of professional skills improvement significantly extends the quality of the educational process using the best educational and methodological achievements of the departmental and also other educational institutions which provide upgrading of personnel's personal skills.

\section{References}

1. Naukovyi visnyk Mizhnarodnoho humanitarnoho universytetu. Ser.: Yurysprudentsiia [Scientific Bulletin of the International Humanitarian University. Series: Jurisprudence]. - 2013. - № 6-1, tom 1. - S. 149-152 (in Ukrainian). 
2. Butko M. P. Rehionalni aspekty formuvannia suchasnoho kadrovoho potentsialu $\mathrm{v}$ orhanakh vykonavchoi vlady ta mistsevoho samovriaduvannia [Regional aspects of formation of modern personnel potential in executive authorities and local self-governments] // Yevroatlantykinform. - 2005. № 5. - S. 42-43 (in Ukrainian).

3. Chaika L. V. Problemy pidvyshchennia kvalifikatsii miskykh holiv [Problems of city heads' qualification improvement] // Visnyk Natsionalnoi akademii derzhavnoho upravlinnia. - 2010. - № 3. - S. 70-77 (in Ukrainian).

4. Kisil Z. R. Stratehiia reformuvannia prokhodzhennia derzhavnoi sluzhby v OVS Ukrainy [The strategy of civil service in the ATS of Ukraine reforming] // Naukovyi visnyk Lvivskoho derzhavnoho universytetu vnutrishnikh sprav. - 2015. - № 1. - S. 201-210 (in Ukrainian).

5. Duka O. A. Vymohy do personalu Derzhavnoi kryminalnovykonavchoi sluzhby Ukrainy: profesiinyi ta moralno-etychnyi aspekty [Requirements to the personnel of the State Criminal and Executive Service of Ukraine: Professional and moral-ethical aspects] // Yurydychna psykholohiia ta pedahohika. - K.: NAVS, 2014. - Vyp. 1 (14). - S.79-91 (in Ukrainian).

6. Nychkalo N. H. Neperervna profesiina osvita yak filosofska ta pedahohichna katehoriia [Continuous professional education as a philosophical and pedagogical category] // Neperervna profesiina osvita: teoriia i praktyka. - 2001. - Vyp. 1. - S. 9-22 (in Ukrainian).

7. Zakon Ukrainy pro Derzhavnu kryminalno-vykonavchu sluzhbu Ukrainy [The Law of Ukraine on the State Criminal and Executive Service of Ukraine] // Ofits. visnyk Ukrainy. - 2005. - № 29. - St. 1697 (in Ukrainian).

8. Pro zatverdzhennia Polozhennia pro orhanizatsiiu profesiinoi pidhotovky osib riadovoho i nachalnytskoho skladu Derzhavnoi kryminalnovykonavchoi sluzhby Ukrainy [On Approval of the Provision on Organization of Professional Training of Persons of the Private and Chief Staff of the State Criminal and Executive Service of Ukraine]: nakaz Ministerstva yustytsii Ukrainy vid 08 veresnia 2015 r. [Decree of the Ministry of Justice of Ukraine dated September 8, 2015] № 1675/5 // Ofits. visnyk Ukrainy. 2015. - № 76. - St. 2546 (in Ukrainian).

\section{ФОРМИ ПІДВИЩЕННЯ КВАЛІФІКАЦІЇ ПЕРСОНАЛУ ДЕРЖАВНОЇ КРИМІНАЛЬНО-ВИКОНАВЧОЇ СЛУЖБИ УКРАЇНИ: ПЕРЕВАГИ ТА НЕДОЛІКИ}

Проведено аналіз стану наукової розробки системи підвищення кваліфікаиії державних службовців циивільного та мілітаризованого складу. 3'ясовано, щзо прочес підвищення кваліфікації здійснюється завдяки застосуванню зовні- 
шніх та внутрішніх форм. Визначено суб'єктів підвищення кваліфікації пенітенціарного персоналу, серед яких слід назвати навчальні заклади Державної кримінально-виконавчої служби та навчальні заклади, які підпорядковані органам виконавчої влади центрального та місиевого рівня. Проаналізовано переваги та недоліки як зовнішньої, так і внутрішньої форм підвищення кваліфікачії. Сформульовано висновки стосовно ефективності поєднання у чинній системі підвищення кваліфікаиії персоналу зовнішньої та внутрішньої форм удосконалення професійної майстерності персоналу.

Ключові слова: Державна кримінально-виконавча служба України, пенітенціарний персонал, система підвищення кваліфікаџї персоналу, зовнішні форми підвищення кваліфікачії, внутрішні форми підвищення кваліфікащії, переваги та недоліки підвищення кваліфікаиії персоналу.

\section{Ребкало Н. Н. ФОРМЫ ПОВЫШЕНИЯ КВАЛИФИКАЦИИ ПЕРСОНАЛА ГОСУДАРСТВЕННОЙ УГОЛОВНО-ИСПОЛНИТЕЛЬНОЙ СЛУЖБЫ УКРАИНЫ: ПРЕИМУЩЕСТВА И НЕДОСТАТКИ}

Проведён анализ состояния научной разработки системь повышения квалификации государственных служащих гражданского и милитаризованного назначения. Установлено, что процесс повыцения квалификащии осуществляется через внешние и внутренние формы. Определены субъекты, осуществляющие повышение квалификации пенитенциарного персонала, среди которых следует назвать учебные заведения Государственной уголовно-исполнительной службы и учебные заведения, которые находятся в ведении органов исполнительной власти центрального и местного уровня. Проанализированы преимущества и недостатки как внешней, так и внутренней форм повымения квалификачии. Сформулированы выводы относительно эффективности сочетания в действующей системе повыщения квалификаиии персонала внешней и внутренней форм совершенствования профессионального мастерства персонала.

Ключевые слова: Государственная уголовно-исполнительная служба Украины, пенитенцииарный персонал, система повышения квалификации персонала, внешние формы повышения квалификации, внутренние формы повышения квалификации, преимущества и недостатки повымения квалификации персонала. 